\title{
The Role of Sistani People in the Uprising of IbnAsh'at against Umayyad Caliphate System (80-85 A.H.)
}

\author{
Mohammad Reza Pordeli ${ }^{1}$, Doostali Sanchooli ${ }^{1}$, Maryam Mollashahi ${ }^{1} \&$ Malihe Abvysany ${ }^{1}$ \\ ${ }^{1}$ Department of History, Zabol University, Zabol, Iran \\ Correspondence: Mohammad Reza Pordeli, Department of History, Zabol University, Zabol, Iran. E-mail: \\ M.mpordeli@uoz.ac.ir
}

Received: March 29, 2017

Accepted: April 10, 2017

Online Published: May 18, 2017

doi:10.5539/res.v9n2p301

URL: http://doi.org/10.5539/res.v9n2p301

\begin{abstract}
Encountering Muslim Arabs and Islam in the first hegira century, Sistani people showed two kinds of reaction. Many of them did not resist Islam and its divine teachings and gradually converted to this new religion; however, they stood up to the racist and oppressive dominance of Umayyad family and whenever they got an opportunity, they expressed their hatred towards them by joining anti-Umayyad uprisings. Abdolrahmanibn Mohammad ibnAsh'at was one of the anti-Umayyad uprisings. Many of Sistani people took part in this uprising. In the present study, the descriptive - analytical research method has been used and with the help of library sources, the role of Sistani people in the uprising of ibnAsh'at against the Umayyad caliphate system has been reviewed. Due to dissatisfaction of Sistani people with the oppressive Umayyad governance, Khawarij's anti-Umayyad propaganda in Sistan region, exponential financial and bodily costs resulting from successive wars of the Umayyad governors in eastern borders with the governance of Ratabilan, the essential substrate was built for Sistani people to join ibnAsh'at's anti-Umayyad uprising. Although this uprising failed, but it weakened the pillars of the Umayyad governance and it proceeded to the extent that Umayyad family was on the verge of being falling and it also paved the way for the anti-Umayyad uprisings subsequent to it.
\end{abstract}

Keywords: ibnAsh'at uprising, Sistani people, Umayyad caliphate system, HojajibnYusef Thaqafi

\section{Introduction}

Umayyad Caliphate was established on the basis of the ethnicism present in the pre-Islamic era. Not only it evoked a feeling of hatred in non-Arabs and Mawali, but, by moving further away from human and divine teachings of Islam, it created a sense of dissatisfaction in Arabs as well. The process of violence and repression of those who were against the Umayyad caliphate system became more intense at time of governance of Abdolmalekibn Marwan; and HojajibnYusef Thaqafi, who was an agent of the caliphate in Iran and Iraq, played a crucial role in this field. Expansion of violence and oppression led to creation of numerous anti-Umayyad uprisings and rebellions, one of which was the uprising of Abdolrahmanibn Mohammad ibnAsh'at. In this uprising, various groups of Arab and non-Arab Muslims, including Sistani people, were effectively active.

Encountering Muslim Arabs and the Islam in the first hegira century, Sistani people showed two kinds of reaction. Many of them did not resist Islam and its divine teachings and gradually converted to this new religion; however, they stood up to the racist and oppressive dominance of Arab's pre-Islamic culture, that the Umayyad family attempted to promote after coming to power, and whenever they got an opportunity, they expressed their hatred towards them by joining anti-Umayyad uprisings.

IbnAsh'at uprising is one of the uprisings which has been studied by researches from various angles, but the role of Sistani people in it has not been mentioned frequently. Reviewing the anti-oppression and truth-seeking spirit of the people in this land helps us stand up to oppression and injustice of tyrants and not to give in to their oppressions and accept the truth and what is right and try to develop the original Islamic culture. The present study has aimed to answer the following questions:

1) Why did Hojaj send IbnAsh'at to Sistan?

2) What were the reasons behind IbnAsh'at's uprising in Sistan against the Umayyad caliphate?

3) What were the reasons behind Sistani people joining IbnAsh'at's uprising against the Umayyad family? 


\section{Method}

The study's method is descriptive - explaining, along with critical view is.

\section{Results}

\subsection{IbnAsh'at Family in Political Endeavors}

Abdolrahmanibn Muhammad ibnAsh'atibnQeys, also known as ibnAsh'at, has been one of the well-known military and political figures throughout the course of Umayyad's governance. He was the grandson of Ash'atibnQeys who was the chairman of Kendeh tribe. In the 10th year of hegira, Ash'at converted to Islam in the current of apostasy and defiance of the tribes in the early period of the apostate and he was the muezzin "Sajah" who claimed to be prophet (Yaghoobi, Bita, Vol. 2, p. 130). He then surrendered to Islamic armies and went to Abu Bakr. The Caliph granted him forgiveness and he married Caliph's sister "Om Forooh". They had 5 children together named Abdolrahman, Is'haq, Qaribeh, Hobabeh and Ja'deh (Balazari, 1988, p. 107; Yaghoobi, Bita, Vol. 2, p. 133). At the time of governance of Imam Ali and throughout the battle of Siffin and after the battle, he played a role in the current of Khawarij's instigation as well as in keeping people from becoming prepared to go to war with Muawiyah for a second time. Imam Ali gave him the nickname "Orf Al-Nar" during the battle that was going on between him and Muawiyah (Balazari, 1988, p. 107). Muhammad ibnAsh'at sided with the Umayyad family in the Karbala incident and Imam Hossein's uprising and was killed at the time of the uprising of Mokhtar. Abdolrahman is the son of Muhammad who outed the house in which Muslim ibnAqil was hiding at one time to Obeydollahibn Ziad who was the governor of Kufa (Al-bazari, 1417, Vol. 2, p. 82). In the year $67 \mathrm{~A}$. H., when he was 27 years old, he replaced his father and became the chairman of Kendeh tribe (Golshani, 1990, Vol. 3, p. 17) and went to war with Mokhtar along with Mosa'ebibn Zabir. There is a probability that he encouraged Mosa'eb to kill the slaves who were companions of Mokhtar to get even with him for killing his father or that he was the one who attempted to kill them (Vagliri, 2004, p. 168). Ash'at's family were not on good terms with the family of the prophet. Quite conversely, they were on great terms with the Umayyad family which is an indication of their ambition. Maintaining power in the field of politics was always their most significant goal.

From the beginning of the period during which the Umayyad family came to power, Abdolrahman sided with them and supported them and that is why HojajibnYusef Thaqafi, who had been appointed as Iraq's governor by Abdolmalekibn Maravan, sent him to Sistan. Hojaj held a grudge against Abdolrahman and hated him. It has been said that Hojaj had said that "whenever I look at this man (Abdolrahman), I want to chop his head off (Tabari, 2008, Vol. 6, p. 328; Dinvari, 1989, p. 318). Despite the fact that Hojaj did not trust ibnAsh'at, he sent him to Sistan as the head of an equipped and strong army of Arabs' bravest and greatest. In addition to giving the fighters allowances, he spent 2 million dirhams on the army and that is why this army came to be known as Sepah-e Taavoosan (Note 1) (Tabari, 2008, Vol. 6, p. 330; Balazari, 1997 (Note 2), Vol. 7, p. 310). Some believe that this army was called Sepah-e Taavoosan (Jeysh Attavavis) because it had influential and skilled Iraqi leaders who were therefore self-opinionated or because they were quite embellished (Dent, 1979, p. 6). The author who has written the history of Sistan has said: "this army has been named Jeysh Attavavis because it was comprised of noble and great people” (Sistan's history, 2008, p. 137).

\subsection{Reasons behind Selecting IbnAsh'at and Sending Him to Sistan}

Despite the fact that Hojaj did not trust ibnAsh'at, the most important reasons for selecting him as the head of the equipped army and sending him to Sistan are as follows:

1) Keeping those that were dissatisfied and opponents further away from Iraq and keeping them occupied in remote areas: according to a letter written by HojajibnAsh'at to their soldiers, such a goal is clear. Hojaj orders them to cultivate crops and do farming in Sistan and realm of Ratabil and they were not allowed returning to Iraq until the final victory and that their home was there (Tabari, 2008, Vol. 6, p. 336). Soldiers and their leaders found out about Hojaj's intentions and objected and wanted to take Hojaj down from a position of power and said that he has sent you to remote areas until you die (Tabari, 2008, Vol. 6, p. 337). Hojaj was not happy and satisfied with them and did not trust them. In response to the opponents of ibnAsh'at and his companions in this mission, he said that: "I sent him there (Sistan) with a number of hypocritical and two-faced people" (Dinvari, 2001, p. 261). It is clear that Hojaj wanted to get rid of them.

2) Suppression and destruction of Sistan's KHawarij: Khawarij has had obtained so much power in Sistan and also many of the Sistani people supported them and they had made the conditions difficult for the Umayyad governors. When Hojaj received the news that Sistani people had joined Khawarij, he sent Abidollah Abibakreh to Sistan with a large army. Abidollah sent Harish ibnBastamTamimi to that area along with a large group of 
soldiers. When Harish and his companions got to Sistan, Sistani people and Khawarij got into a tough battle with them and killed many of them. The rest of the army also died of hunger and thirst. The few of the members of the army who survived the battle died because of overeating after entering the city. Arabs called this army Jeysh Al-fana (Sistan's history, 2008, p. 136). After this incident, Khawarij came to power in Sistan to the extent that before ibnAsh'at got to Sistan, Bobarde'eh, the governor of Sistan, Khurasan's governor asked Mohallebibn AbiSafarah for help and said "send a hard-working man with an army so that the pillars of what I built won't be weakened because the number of Khawarij in this area has increased" (Sistan's history, 2008, p. 138). When ibnAsh'at got to Sistan, Homamibn AdiSadoosi, the great leader of Khawarij, got into a battle with him. Although Khawarij lost, a large group of the both sides of the battle died throughout the course of it (Sistan's history, 2008, p. 138). Hojaj felt the risk caused by Khawarij' coming to power and sent a powerful person to Sistan to suppress them so that no harm would come to the power of the Umayyad caliphate system.

3) Tribal and individual traits of IbnAsh'at: it was because of the military and political position and power of Ash'at's family that Hojaj arranged for Meymooneh, the daughter of Muhammad ibnAsh'at and his son Muhammad to get married when he was in Iraq and that was how he made peace with the Ash'at family and exploited their power and influence (Dinvari, 2001, p. 260). Cooperation of Abdolrahman and his family with the Umayyad family on one hand, and lack of an accurate knowledge of the personality of ibnAsh'at by Hojaj on the other one, forced Hojaj to send ibnAsh'at to Sistan. Hojaj thought that Abdolrahman feared his power and wouldn't do anything against him. When IsmaeilibnAsh'at, Abdolrahman's uncle, disagreed with his selection as the commander of the army and his sending to Sistan and said: I swear to God, he won't obey the orders as soon as he crosses the Euphrates Bridge. Hojaj told Ismaeil: Abdolrahman is afraid of my power and awe and he won't disagree with me or rebel against me (Balazari, 1997, Vol. 7, p. 311; IbnAsir, 2006, Vol. 4, p. 456); while according to some reports, when ibnAsh'at was selected as the governer of Sistan, he had the thought of bringing down Hojaj from a position of power in mind (Dinvari, 2001, p. 261). Of course, ibnAsh'at, with his subtlety and perception, has acted in such a way that Hojaj could not discover his intentions. In order for compensating for the failure of Muslims in Ratabil and for the continuation of the conquests and reception of taxes, IbnAsh'at was considered as a quite adequate option for the goals of Hojaj to be met in this mission. Before ibnAsh'at's pilgrimage to Sistan, on behalf of Abdolmalikibn Marwan, Hojaj made Umayyehibn Abdollah the governor of Khurasan and Sistan. He gave the responsibility of Sistan to his son Abdollah. After a while of living in Sistan, he marched into Ratabil realm and when he reached the city of Bost, Ratabil also sent a representative to him and asked for peace and suggested a 2-million-dirham reward, presents and slaves. Abdollah downplayed the offer and said: I will only accept the offer if he fills this room (hall) with gold. Ratabil and his soldiers retreated into their own homelands after receiving the offer and made them follow their trace to mountainous regions and then closed the pathways and roads to them and ambushed them. Abdollahibn Umayyad was also forced to pay 300 thousand dollars to Ratabil and made a commitment that as long as Ratabil is in charge of Sistan's governance, they wouldn't go to war with him or put a part of his lands on fire or destroy it and save themselves and their soldiers from that perilous situation (ibnAsir, 2006, Vol. 4, p. 369; Sistan's history, 2008, p. 134; IbnKhaledoon, 2004, Vol. 2, p. 85).

\subsection{Sistan's Situation on the Verge of IbnAsh'at's Uprising}

IbnAsh'at and his army entered Sistan in the year 80 A.H. and informed people of their goals and objectives. In a sermon read to people, he said: Amir Hojaj has made me the governor of your land and has ordered me to fight your enemies looting your land and destroy the good people of your land. Those of you who don't go to this camp will be punished; go to the army camp and join them. People went to the military camp. There were some markets for the army to supply the tools and weapons they needed for war. When Ratabil got this news, he wrote a letter to Abdolrahman and apologized for the harm he had caused the Muslims and said: he didn't intent to fight the Muslims and it was the Muslim's own doing that made him do so. Then, he offered peace and stated that he would pay taxes (Tabari, 2008, Vol. 6, p. 329).

IbnAsh'at did not accept Ratabil's offer and ordered the army to move into Ratabil's lands and the Ratabil army retreated. Muslims conquered their castles one after the other and moved farther and farther into the land and achieved prizes. Then IbnAsh'at stopped the war and postponed the rest of the war to Ratabil realm to next year. He gave the news of victory and achievement of prizes to Hojaj and asked him to stop the war so that the pathways and regions of Ratabil land would be identified and taxes would be collected (IbnAsir, 2006, Vol. 4, p. 462). When Hojaj got the news, he wrote a letter to IbnAsh'at and expressed his unhappiness with the interruption of the war that was going on and mentioned the point that your letter is a letter of a person who loves to quite the war and stop it and is interested in peace and shows kindness to despicable enemies who had destroyed a brave, hard-working and deserving army of Muslims. You consider me an enemy, take the blood of 
Muslims who have been killed throughout the process lightly and sacrifice their lives. Go do as I ordered you and move farther and farther into their lands, destroy their castles and fortresses, kill their soldiers and take their women and children as slaves (Tabari, 2008, Vol. 6, pp. 335-336; IbnAsir, 2006, Vol. 4, p. 461).

\subsection{How IbnAsh'at's Uprising Happened and Why Sistani People Joined the Cause}

After sending Hojaj's letters, which were quit threatening and humiliating (Ref: IbnKasie, 1986, Vol. 9, p. 35), IbnAsh'at gathered Sistani people and army and said to them: I have your best interest at hear and I have consulted wise men and brave warriors, who had extensive experience in this matter, and got their blessing and reassurance about your present and future benefit. I wrote about my opinion to your governor Hojaj and he has responded to my letter and has called me weak and disabled and has ordered me to move you further into the land of enemy which is the land in which your brothers died yesterday. Of course, I am one of you and if you act, I will act; if you don't accept something, I won't accept it either. Some stood up and said: "we won't take the words of one who is god's enemy and we won't listen to him or obey him" (Tabari, 2008, Vol. 6, p. 336). Abdolrahman was upset about Hojaj's allegation and the fact that he called him timid and incompetent and in the speech he presented to people and their army, he granted them freewill as far as acceptance of Hojaj's offer was concerned and expressly explained the opinion of war experts to them. The soldiers chanted that they won't obey Hojaj. Abotafil AmeribnVaeleh Kanani, the well-known Sahabi poet and narrator, said: "Hojaj is not afraid of getting you to a large and wide land surrounded by elevated mountains and unknown valleys. If you achieve victory and prizes, he will benefit and it is his wealth and assets that would increase and the realm governed by him becomes wider and if you lose to your enemy, you are the enemy who is going to be blamed and he succeeds in getting rid of your (ibnAsir, 2006, Vol. 4, p. 463). Some other well-known figures also wanted Hojaj to fail and lose his position and took an oath to stay loyal to IbnAsh'at; therefore, this rebellion became absolute and certain.

Sistani people, both Arabs and non-Arabs, expressed their disagreement and objection about Hojaj and Umayyad caliphate system and supported IbnAsh'at and his companions; because they were not satisfied with what the Umayyad agents were doing at the time. "Arabs thought that any land, garden, tree, farm or animals were their own and the most extreme actions were taken Umayyad family. As Saeed ibnAas said: Iraq is Qoreysh's garden" (Zeydan, 1993, p. 684).

The most important reasons behind Sistani people's disagreement with the Umayyad caliphate system were as follows:

1) In these years, in Sistan, there was an increase in Khawarij's propaganda against the Umayyad caliphate system and their anti-religion measures. The one who has written Sistan's history has praised Khawarij of that time and has said that: "in each region, when there has been an uprising against the Umayyad family, people have embraced it". "Their leaders were great Arab figures who were Mostafa's companions. When things got complicated between Muslims that were against what the holy book-Quran-said and what was against common sense, they turned against it" (Sistan's history, 2008, p. 134). He then cited some of the events and incidents that occurred in the Islamic community after the holy prophet died. Among these occurrences, we can refer to the murder of Uthman and Ali, wars of Jamal and Siffin, murder of Imam Hossein and Abdollahibn Zabir, destruction of Mecca - the shrine of god - with stones and catapults and unfair murders and injuries, etc. These incidents were hard to handle for people and that it is why the number of Khawarij increased day by day (Sistan's history, 2008, p. 135). Since Khawarij believed that one must absolutely stand up to an oppressive caliph (Baghdadi, 1954, p. 42; Moghadassi, Bita, Vol. 5, p. 135), Sistani people believed that Umayyad caliphs were tyrants and oppressors; therefore, this belief was shared by Sistani people and opponents of the Umayyad caliphate system made them cooperate with one another and they collaborated with ibnAsh'at because they all were against the Umayyad family and that is why they participated in the uprising against the Umayyad family.

2) Unproductive wars of Umayyad governors in Sistan with eastern lands, including Ratabil, imposed costs and expenses of enormous size for preparing for war and supporting it on the people of that region. The author who has wrote Sistan's history has mentioned that Hojaj has written a letter to Abdolrahman and asked him to "take people's property and assets and move to Hend and Sand" (Sistan's history, 2008, pp. 138-139). Obviously, this order was given to all of the Umayyad governors in Sistan. They were supposed to take people's properties to prepare themselves for wars and spend them on their battles. Usually, this type of wealth was collected violently and by force and people were not happy with this situation; therefore, they joined ibnAsh'at with the hope of improving the situation.

3) Hojaj's order to ibnAsh'at regarding the murder of Abdollahibn Amer, who was one of the great figures in Sistan, was a factor that affected the hatred towards Hojaj and people's dissatisfaction with him. Abdollah was 
someone who played a crucial role in bringing peace, safety and compliance between opposing political-religious sides in Sistan and that is why he was popular. Hojaj ordered ibnAsh'at to bring Abdollah's head to him. Not only IbnAsh'at didn't do so, but he also befriended Abdollah and informed him about Hojaj's intention and wrote to Hojaj: "I will move to Hend and Sand, but I won't take unfair actions and I won't kill without having a reason and no obedience to a creature in the sin of the creator" (Sistan's history, 2008, p. 139). Abdollahibn Amer was considered an influential individual in the land and ibnAsh'at "consulted him when he wanted to express an opinion or wanted to make a strategy and Sistani people were on AbdollahibnAmer's side" (Sistan's history, 2008, p. 138). Given Abdollahibn Amer's social status and influence, his support was a proper back-up for ibnAsh'at's uprising at that time.

4) Abdolrahman's supporters' propaganda against Hojaj and the Umayyad caliphate was an effective factor that stimulated Sistani people and their opposition. Many of Shiite scholars and Iraqi reciters supported ibnAsh'at and his opposition with Hojaj and the Umayyad family. According to the reports of the author who wrote Sistan's history, many scholars were companions of ibnAsh'at in Sistan and in sessions and assemblies, they warmed people's heart to ibnAsh'at and informed people of Hojaj's injustice, anti-human and anti-Islam actions and made sure that people secretly and covertly swear to allegiance to ibnAsh'at (Sistan's history, 2008, p. 139). These kinds of action made Sistani people to support ibnAsh'at and his uprising against Hojaj and the Umayyad governance and to help him.

\subsection{Nature of the Uprising and What Happened to IbnAsh'at}

Although ibnAsh'at's uprising was a political one at first, but it turned into a political-religious nature when a large number of scholars and reciters came into the picture including Hassan Bassari, Ameribn SharhbilSha'bi and Saeed ibn Jabir and Ibrahim Nakha'ee and a group of such people (Yaghoobi, Bita, Vol. 2, p. 279). They believed that Hojaj's actions and behaviors and Sham's governance was against Islamic rules. Some of the statements of reciters and believers are indicative of this point. Abolbakhtari, who was a supporter of ibnAsh'at's movement, said: O people! Fight to keep your religion and your world. Sha'bi also stated: fight them and don't fear it. I swear to god I don't know a tribe more oppressive than this one and there is no governance more tyrannical than theirs. Saeed ibn Jabir said: fight them for they are sinners and their governance is tyrannical and their religion is oppressive, they humiliate those that are weak and destroy prayers (Tabari, 2008, Vol. 6, pp. 358-359). This kind of statements evoke people's rage and hatred towards Hojaj and the Umayyad family. Their oppression and murders were the reason behind the fact that followers and scholars of Hijaz and Iraq became ibnAsh'at's allies and agreed to go to war against Hojaj" (Mostofi, 1985, p. 276).

In addition to the political-religious nature of the uprising, many people, including non-Arabs, joined the movement to get rid of the oppression of the Umayyad caliphate system. Many of Sistan's non-Arabs, like Firooz Mavel Hossein, joined ibnAsh'at's uprising against Hojaj because of this (Gardizi, 1984, p. 231). Firooz was from Sistan and he was of one of the noble Iranian families. Over the governance of Imam Ali, when the caliph sent an army to Sistan, Firooz converted to Islam in one of the wars and became a companion of an Arab leader called Hosseinibn Abi Alhar and went to Basareh with that army and stayed there (Balazari, 1988, p. 384). Firooz was one of the leaders of ibnAsh'at's armies in the wars against Hojaj. In one of his battles, he killed 70 of the leaders of Hojaj's army in a day. "At the end he shouted what is Hojaj to you? Hojaj made a promise that anyone who brings his head to me will be granted 10 thousand dirhams" and when Firooz heard this statement, "he told his army that anyone who brings Hojaj's head to me will be granted 100 thousand dirhams and a horrible battle happened that day. At the end, Hojaj returned to Hazimat. Although Firooz was a scholar, he was a great warrior" (Sistan's history, 2008, pp. 62-63). IbnAsh'at had a number of 200 thousand soldiers and 100 thousand of them were non-Arabs (Vagliri, 2004, p. 174). It is obvious that the oppression of the Umayyad family made non-Arabs join ibnAsh'at in this uprising and Firooz of Sistan was one of them.

Numerous wars happened between ibnAsh'at and Hojaj. IbnAsh'at and his followers won most of them and it wasn't until the year 83 A.H. that Abdolrahman lost in Dir Al-Jamajem and returned to Sistan. However, Abdollahibn Amer, whom had been selected by ibnAsh'at as the governor of Sistan, banned him from entering the city of Zaranj after his failure and return from Iraq to Sistan (Bal'ami, 1999, Vol. 4, p. 806). Abdollah wanted to keep the people of Sistan safe from Hojaj's rage and vengeance. IbnAsh'at then was forced to go to Bost. Bost's governor welcomed him, but a little bit later, he arrested ibnAsh'at. As soon as Ratabil received the news and freed him, he took him with himself and treated him with respect and integrity (Yaghoobi, Bita, Vol. 2, p. 279; ibnAsir, 2006, Vol. 4, p. 486). Hojaj sent AmarehibnTamim Al-qeysi to Ratabil and secretly threatened Ratabil to send ibnAsh'at to Hojaj. According to some reports, ibnAsh'at committed suicide on the way and jumped from the roof of a castle and died in the year 85 A.H. (Sistan's history, 2008, p. 142; Haji Khalifeh, 1997, p. 48). 
After ibnAsh'at failed in Iraq, Firooz and a large number of ibnAsh'at's soldiers went to Sistan and then Khurasan and it was in Khurasan that they lost in a war with Yazidibn Mohalleb, Hojaj's representative and became a slave. Yazid sent him to Hojaj (Tabari, 2008, Vol. 6, p. 374; ibnAsir, Vol. 4, p. 488). Because of Hojaj's order, Firooz was tortured. One of the ways he was tortured was that they put his organs in a straw slot and stretched it so much that the skin of the organ would crack open and bleed and then they poured vinegar on it. Hojaj demanded a statement of Firooz's assets from him. He said: write down one thousand thousand, two thousand thousand and talked a lot about assets. Hojaj demanded these assets. Firooz said: take him among people to give to him the assets that is under control of people. Despite Hojaj's expectation, when they took him among people, they said to them: anything I have that is under your control is now yours. Don't give them to anybody and inform those who aren't here. That is how he deprived Hojaj from owning his assets and that is why he was killed (Tabari, 2008, Vol. 6, p. 380; ibnAsir, 2006, Vol. 4, p. 490). After the end of ibnAsh'at's uprising, non-Arabs came to be known as the most dangerous rebellions in the perspective of Hojaj and ten thousand of them were punished (Vagliri, 2004, p. 182).

Jorji Zeydan wrote: Hojaj tortured his opponents before killing them. He cut the straw and used straw resins to injure their bodies. Then he poured vinegar and salt on the wounds and tortured them to the point of their death! Hojaj did the same with the companions of ibnAsh'at with the maximum intensity. His opponents did the same and tortured their enemies in the worst way possible (Zeydan, 1993, p. 727). This is an indication that many of those who called themselves Muslim were far from the true Islam. Some have written about Hojaj's wrong doings: "many of those who had gone to Hojaj were killed, except for 200 thousand men who were killed differently" (Bal'ami, 1999, Vol. 4, p. 809). When Hojaj died, he had 50 thousand men and 30 thousand women as prisoners (Zeydan, 1993, p. 725).

Some of the Banihashem family, including Abdolrahmanibn Abbas ibnRabi'ehibnHareth Abdolmotalleb, joined the uprising of IbnAsh'at. After ibnAsh'at lost to the Umayyad army and returned to Sistan, Abdolrahmanibn Abbas and his followers and the rest of the runaway army went to Sistan and gathered around in Zaranj, the capital of Sistan and appointed Abdolrahmanibn Abbas Hashemi as their governor (Yaghoobi, Bita, Vol. 2, p. 280; Balazari, 1997, Vol. 7, p. 350; ibnKhaledoon, 2004, Vol. 2, p. 102). This group wrote a letter to ibnAsh'at and asked him to come to Sistan and join them. IbnAsh'at came to them. Despite ibnAsh'at's insistence on staying in Sistan and fighting the Umayyad family, Abdolrahmanibn Abbas insisted on going to Khurasan and ibnAsh'at was forced to accept. When they reached Herat, Abdolrahmanibn Abbas Hashemi parted ways from ibnAsh'at and took two thousand of his followers along and ibnAsh'at was forced to return to Ratabil (Bal'ami, 1999, Vol. 4, p. 807; ibnKhaledoon, 2004, Vol. 2, p. 102). The separation of Abdolrahmanibn Abbas from ibnAsh'at has not been discussed in the sources. The disagreement about the continuation of the war with the Umayyad family might be the cause of this separation. Presumably, when Abdolrahmanibn Abbas was in Sistan, he had found out that he could not rely on Sistani people for supporting him and his companions and that is why he insisted on going to Khurasan so that he would benefit from the support of Khurasani people, because they had supported Banihashem before.

Oppression was considerably increasing during the period of governance of the Umayyad family and this increase played a crucial role in the emergence of popular uprisings. IbnKhaledoon has written: "it is in Arabs' nature to steal whatever they find when the defeat people and to ignore everything else. They don't care about governance and defending the rights of some against others. Thus, whenever they defeat a nation, their ultimate goal is to benefit from stealing people's assets and except for this goal, they don't care about anything else whether it is legislation, giving orders to people that would help them. Perhaps, due to the greed for adding to taxes and achieving more benefits, they determine financial penalties for the sinners, but it is obvious that these kinds of rules and regulations cannot be called the power of the governor, but they are considered as causes of corruption and wickedness based on intentions that stimulate those who pay ransom and that is how the rate of sin and corruption increases and civilization turns into destruction and such a nation would face chaotic conditions and anyone could do wrong. It is clear that civilization of such a tribe could not be improved and chaos destroys the country rapidly. That is why it is not in Arabs' essence and nature to govern a country with good policies and they can only do so by changing their nature and turn their governance power to religious customs and that is how they will be rid of their bad nature (ibnKhaledoon, 1996, Vol. 1, pp. 290-291). The Umayyad family distanced themselves from politics as soon as they forgot Islam and that is when they returned to rustication (ibnKhaledoon, 1996, Vo. 1, p. 292). Therefore, killing people, avoiding divine values and returning to the values of pre-Islam era, the way was paved for anti-Umayyad uprisings and provided the substrate for the fall of the Umayyad caliphate. 
IbnAsh'at's movement is considered as one of the movements created by Iraqi people against the Umayyad caliphate and Iranian people, especially Sistani people, also took part in it. This movement weakened the pillars of the Umayyad governance and it became too close to falling (Taghoosh, 2001, p. 94). IbnAsh'at's battle with Umayyad family after the war of Siffin was the greatest and most horrible war between Muslim to this date (Masoodi, Bita, p. 273). This uprising was one of the longest and biggest anti-Umayyad political—religious uprisings of the first hegira century and it was the last political crisis in which Hojaj was able to win and therefore, until his death in the year 95 A.H., no one or no group was brave enough to stand up to him, but the pillars of the Umayyad governance was weakened.

\section{Discussion}

The violence, suppression and oppression policy adopted by the Umayyad family on one hand and their distancing themselves from principal Islamic teachings on the other one, led to creation of numerous protest-oriented uprisings throughout their caliphate, especially the period of governance of Abdolmalekibn Marwan. Sistan was one of the regions in which opponents of the Umayyad caliphate system were quite active and threatened their governance. In the year 80 A.H., Abdolrahmanibn Muhammad ibnAsh'at was sent to Sistan to save Iraqi people from threats as the leader of an army by Hojaj who was Iraq's governor appointed by the caliph. By doing this, Hojaj aimed to send opponents away and create a distance between them and Iraq, to suppress the rebellion of Khawarij in Sistan and to compensate for numerous failures of the Umayyad soldiers against Ratabilian in eastern borders. When ibnAsh'at got to Sistan and the substrate was built for the uprising against the Umayyad family, he revolted against Hojaj and the Umayyad family. In this uprising, in addition to various groups, Sistani people also joined the movement. Sistani people's dissatisfaction with the oppressive governance of the Umayyad family, anti-Umayyad propaganda odKhawarij in the area, exponential financial and bodily costs resulting from successive wars of Umayyad governors in eastern borders with the governance of Ratabilan, were the reasons behind Sistani people's participation with the those who revolted. Although the nature of the uprising was a political one at first, but it turned into a political—religious nature when different groups of people who were not happy with various policies adopted by the Umayyad caliphs and their agents and the Umayyad caliphate came close to dethronement. Although the uprising failed, but it was one of the longest and biggest anti-Umayyad political-religious uprisings of the first hegira century and exponentially weakened the Umayyad caliphate system and the pillars of their governance and their governance came close to falling. Sistani people, including Firooz, played a crucial role in this uprising.

\section{References}

Albazari, A. A. Y., \& Fotooh, A. B. (1988). Beirut, Dar vaMaktabeh Al-Helal.

Albazari, A. Y., \& Ensan, A. A. (1417 A.H.). Study of SoheilZakar and RizZarkali. Beirut, Dar Al-Fekr.

Anonymous. (2008). Sistan's history (T. B. Mohammad, Ed.). Tehran: Moeen.

Bal'ami, A. (1999). Tabari history (2nd ed., R. Muhammad, Ed.).

Dent, D. (1979). Per capita taxes and their impact on tendency to Islam (A. M. Mohammad, Trans.). Tehran: Khwarizmi publishing corporation.

Dinvari, A. (1979). Akhbar Al-Taval (A. Abdolmoanem, \& S. Jamaleddin, Eds.). Qom, Manshoorat Al-razi.

Dinvari, Q. (2001). Imamatva Siasat (Tarikh-e Kholafa) (N. T. Seyed, Trans.). Tehran: Qoqnoos.

Gardizi, A. S. A. Z. (1985). Zeyn Al-Akhbar (Gardizi history). Tehran, world of books.

Golshani, A. (1990). The great Islamic encyclopedia (Vol. 3). Tehran: Center of great Islamic encyclopedias.

Haji, K. (1988). Mustafa ibnAbdollah Chalapi (A. T. Taghvim, Trans., H. M. Mir, Ed.). Tehran: Book revival.

IbnAsir, E. A. (1385 A.H.). Al-Kamel Feltarikh. Beirut: Dar Al-Sader.

IbnKasir, A. I. O., Al-Badayeh, \& Al-Nahayeh. (1986). Beirut: Dar Al-fekr.

IbnKhaledoon, A. M., \& Al-Abar. (2004). IbnKhaledoon's history (A. T. Abdolmuhammad, Trans.). Research center of human sciences and cultural studies.

Masoodi, A. A. H. M. (n.d.). Al-Tanbieh and Al-Ashraf(A. S. AbdollahIsmaeil, Ed.). Cairo, Dar Al-Savi, Bita.

Moghaddasi, M. T. (n.d.). Al-Bad va Al-Tarikh. Bor Saeed, Maktabeh Al-Thaqafeh Al-Dinieh, Bita.

Mostofi, H. (1985). Selected history (N. Abdolhossein, Ed.). Tehran: Amir Kabir.

Shahrestani, A. M. A. (1982). Al-Melal and Al-Nahl (K. H. Mostafa, Trans.). Eghbal press. 
Tabari, A. M. J. T. (2008). Tabari history (Tarikh Al-Amamva Al-Molook) (A. I. Mohammad, Trans.). Beirut, Dar Al-Sarat, Taba'eh Al-Sanieh.

Taghoosh, M. S. (2001). The Umayyad governant (J. Hojatollah, Trans.). Qom: Seminary and University Research Institute.

Vagliri, L. (2004). Vika. IbnAsh'at. Quarterly Journal of History of Islam, 17, 167-186.

Yaghoobi, A. Y. J. (n.d.). Al-Yaghoobi history. Beirut, Dar Al-Sader, Bita.

Zeydan, J. (1993). History of Islam's civilization (J. K. Ali, Trans.). Tehran: Amir Kabir.

\section{Notes}

Note 1. Army of Peacocks.

Note 2. 1417 A.H.

\section{Copyrights}

Copyright for this article is retained by the author(s), with first publication rights granted to the journal.

This is an open-access article distributed under the terms and conditions of the Creative Commons Attribution license (http://creativecommons.org/licenses/by/4.0/). 